\title{
Sustainability of Fiscal Policy in Democracies and Autocracies
}

\author{
Stefan Wurster \\ Institute for Political Science, Trier University, Universitätsring 15, D-54296 Trier, Germany; \\ E-Mail: wurster@uni-trier.de, Tel.: +49 6512012139 \\ Submitted: 3 March 2015 | In revised form: 10 August 2015 | Accepted: 11 September 2015 | \\ Published: 30 September 2015
}

\begin{abstract}
This paper tries to identify the fiscal sustainability record of democratically and autocratically governed countries by applying various performance indicators (payment defaults, national debt, foreign assets) and also to clarify what effect the characteristics of a regime have on consolidation and intertemporal budgeting efforts in a country. Important economic, social and environmental challenges of the future cannot be addressed if long term financial viability is not preserved in a country. The study identifies two key findings: while in the past, democracies have clearly found it easier to preserve their solvency and to avoid government bankruptcy, a similar advantage can no longer be detected for democracies in terms of reducing national debt and foreign debts. Why democracies, in spite of their arrangements with a sensitivity for the public good and for due process, are finding it so difficult to avoid shifting their debts to future generations (to undertake cutback measures and to provide sufficient financial foresight) can in principle be interpreted as the other side of the coin, namely highly presence-oriented interests boosted even further through the short democracy-specific time horizon.
\end{abstract}

Keywords: autocracy; comparative policy research; democracy; regime type; state finances; sustainable government finances

\section{Introduction}

Against the background of the current financial and economic crisis, doubts have clearly increased about the general superiority of countries with a democratic constitution versus autocratically governed countries, in terms of the sustainability of their national finances. Moreover, to preserve long-term solvency and to achieve a balanced intergenerational budget that represents a fundamental condition for sustainable development. This article is grounded in the assumption that important economic, social and environmental challenges of the future cannot be addressed, if long term financial viability is not preserved in a country. The dramatic household situation in several countries on the European periphery (Greece, Italy, Ireland, Portugal, Belgium), as well as other democracies on the globe (Japan, Iceland, USA), raise the question of whether democratic societies may not have systematic deficits in the consolidation of their national finances [1]. In comparison, it seems to have been considerably easier in the past for at least some autocratically governed countries (Kuwait, Russia, Saudi Arabia, China) to keep their national debt under control and to make financial provisions for the future. To what extent these cases can be generalized, what specific cause and effect relationships exist between a country's regime type and the development of its national finances, and what other economic and social factors play an important role in this context in addition to the degree of democratic or autocratic development, is subject of a highly controversial debate in the literature (cf. [2-6]).

In principle, it can be stated that a fiscal policy that is oriented towards the criteria of sustainability is not only ex- 
tremely important for the stability and organizational capability of a modern political system (prevention of government crises through insolvency), but that shifting financial burdens onto the shoulders of future generations should be prevented, also to ensure a development that is fair to all generations (preserving future financial freedom to act) [7].

The special importance of this task explains the focus of our following considerations which is directed towards answers to the following key questions:

- How democratic and autocratic regimes perform in terms of the sustainability of their national finances (measured by the avoidance of payment defaults, the reduction of their national debt and their foreign debt and the altitude of foreign assets)?

- Does the degree of democratization or autocratization really play a significant role in the sustainability of a country's national finances, or could it be that there are other factors involved which influence this to a much greater degree?

To answer these questions, we will first offer some fundamental discussions about the sustainable development of national finances (Section 2) and then provide some thoughts about the relationship between the regime type and sustainable fiscal policy from the aspect of various theoretical approaches (Section 3). After an operationalization of dependent variables (performance indicators for financial sustainability) and independent variables (regime type and other potential explanatory indicators), in the course of which we will also deal with specific data problems in comparing democracy with autocracy, we will provide a quantitative analysis in Sections 4 and 5 (description and explanation of performance results). For that purpose, the study will first of all use descriptive analytical methods (performance determination via a comparison of means). In a second step, the resulting findings will be expanded and deepened by means of multivariate regressions for the more than 130 countries included in the study (small states with less than three million inhabitants were excluded from the study), for the period from 1990 to 2008 [8]. Finally, the results will be summarized and evaluated in Section 6. By following this course, we want to offer a theoretical contribution towards a connection at the interface of regime type and the discourse of fiscal sustainability, as well as providing evidence of existing empirical connections.

\section{Sustainable Fiscal Policy}

Under what conditions a country's fiscal policy can be called sustainable? To answer that question, it is useful, first of all, to look at the general definition of sustainability provided by the Brundtland Commission in 1987. In the sense of intragenerational, as well as intergenerational justice, it means "to meet the needs of the present generation without compromising the ability of future generations to meet their own needs" [9]. The extension of political responsibility beyond the generations living today to include future generations ([10] p. 27; [11] p. 7) implies an orientation towards the principle of making provisions for risks, towards the principle of intergenerational justice (fair equalization of burdens between generations) and the continuous development of opportunities for future generations (cf. [12] p. 28; [13] p. 54). Latitudes must be created today in order to be able to solve future problems.

Translated into sustainable fiscal policy, this means first of all (aspect of risk management) that the present-day budget policy should be such that it can be continued on a sustainable basis without plunging the nation into a financial squeeze (cf. [14] p. 463; [15] p. 807; [16] p. 667). To deal with the serious danger of a government losing its ability to meet its financial commitments (national insolvency) [17], a weak but risk-reducing sustainability can be achieved mainly through preserving a society's credit worthiness and its capacity to pay its debts [18].

For an intergenerationally just fiscal policy (principle of strong sustainability, cf. [19] p. 23), it is also necessary to ensure a just equalization between generations and to prevent the exploitation of future generations (cf. [20] p. 31; [19] p. 110). It can be implied that a government policy that finances a nation through indebtedness is shifting burdens onto the shoulders of future generations (cf. [21] p. 27; [22]), as long as it is not only adjusting temporary fluctuations due to the economy reacting to extraordinary burdens or times of emergency (such as wars, natural catastrophes, etc., cf. [23] p. 294; [24] p. 124; [25]) or corresponding to the Pay-as-you-use principle [26]. In particular, the financing of purely consumer-oriented expenditures can be viewed as problematic (cf. [19] p. 115). A shifting of burdens occurs when subsequent generations experience a direct loss of benefits due to higher taxes necessary to amortize debts and to finance the servicing of debts (cf. [27] p. 250; [20] p. 1). Moreover, an excessive national debt can reduce the dynamics of a country's economic development (crowding out of credit-financed private investments, cf. [16] p. 627) and trigger a negative spiral of interest debt [28]. It could also limit the leeway for future investments (such as R\&D expenditures), resulting in a smaller total capital stock that is passed on to future generations. However, in the opposite sense, to continue providing future generations with opportunities, their financial degrees of freedom and action must be preserved (cf. [29] p. 13) and expanded in the form of the most positive rate of savings possible, by not only investing in the future, but also by forming the greatest possible financial reserves. These reserves are then available in the future to be able to solve important economic, social or environmental problems. Up to what degree it might be useful also to finance investments for the future through indebtedness is a subject of great controversy (cf. [30] p. 173; [31]). The problem of intertemporal budgeting lies in determining the most appropriate taxation rate for future revenues and expenditures ([32] p. 19). Thus, it is in particular the implicit indebtedness of a country that follows primarily from future claims under the pension system (pensions of public servants) or 
the health system that is difficult to assess, since it depends to a major degree on future labour and social legislation and on economic development (cf. [24] p. 221; [33]).

To identify the various dimensions of fiscal sustainability (risk management, intergenerational indebtedness and savings rate) as completely as possible, and to better evaluate the performance of countries, this study uses a total of four performance indicators [34]. Following a trend in policy analysis, we are evaluating the performance of regimes with the help of policy outcome variables [35]. However, since not only democracies, but also autocracies are included in this study, we are incurring a double problem with data. Not only is access to data in autocracies far more difficult (selection bias) [36], but there is also the danger that the data made available may have been systematically falsified. In interpreting data, these problems must always be taken into account, even when-as in this case-generally accepted data sources (World Bank, IMF) are evaluated. To increase the validity of results, we used only such data in our performance evaluation which were obtained without the influence of autocratic states. Thus, we evaluated how nations performed in view of their solvency (risk management), based on the frequency of actual payment defaults (national insolvencies in the past). Consideration of default events (suspension of due payments by a state), even though the exact conditions of a default can vary from case to case (cf. [37]), are based on robust, often used and less controversial data (cf. [38]).

To enable us to identify the (long-term) development of a country's indebtedness situation in the most differentiated form possible, it seemed useful to look not only at a country's general national debt (in relation to its GDP) [39], but also at its foreign debt (as measured by the amount of the country's loans with the IMF) [40]. It can be argued that this foreign debt, in contrast to the debt owed to domestic creditors, is particularly problematic for a state, since some important instruments for lowering it (especially inflationary measures) are not available.

Finally, the picture of a performance evaluation would not be complete without considering a country's intergenerational austerity measures in addition to its mere indebtedness. The accumulation of foreign assets (measured as a country's currency reserves in relation to its GDP) can be regarded as an important indicator.

The performance indicators we used are partly correlated with each other (see Table 1). However, in no case does the measure of association reach a value of more than $r=0.15^{\star * *}$ [41]. Not surprisingly, a particularly close relationship exists between the indicators of national debt and foreign debt. On the other hand, no particularly strong relationship can be detected between national debt and payment defaults. It becomes clear that no deterministic relationships exist in that case if we realize that Argentina-in spite of a national debt of "only" $64 \%$ of GDP in 2001/2002 had to declare national bankruptcy, while Japan with a national debt that by now amounts to almost $200 \%$ of GDP has so far been able to avoid such a step due to its high economic power and low foreign debt (cf. [21] p. 12). Yet accumulated foreign reserves very often seem to go hand in hand with low national debt and a low probability of payment default.

Table 1. Target dimensions of fiscal sustainability and correlation. results

\begin{tabular}{|c|c|c|c|c|}
\hline & $\begin{array}{l}\text { Prevention of payment } \\
\text { default (Source for } \\
\text { payment defaults in a } \\
\text { country [38]) }\end{array}$ & $\begin{array}{l}\text { Low national debt } \\
\text { (Source for national debt } \\
\text { in relation to GDP [42] }\end{array}$ & $\begin{array}{l}\text { Low foreign (Source for } \\
\text { pro capita foreign debt } \\
\text { through IMF loans [42]; } \\
\text { own calculations) debt }\end{array}$ & $\begin{array}{l}\text { High foreign assets } \\
\text { (Source for currency } \\
\text { reserves in relation to } \\
\text { GDP [42]; own } \\
\text { calculations) }\end{array}$ \\
\hline Prevention of payment default & 1.00 & $0.09 * * *$ & $0.12^{* * *}$ & $-0.04 * *$ \\
\hline Low national debt & $0.09^{* * *}$ & 1.00 & $0.15^{* * *}$ & $-0.12^{* * *}$ \\
\hline Low foreign debt & $0.12^{* * *}$ & $0.15 * * *$ & 1.00 & -0.03 \\
\hline High foreign assets & $-0.04^{* *}$ & $-0.12^{* * *}$ & -0.03 & 1.00 \\
\hline
\end{tabular}

\section{Fiscal Sustainability and Regime Type}

Before any statement can be made on a theoretical level about the connection between fiscal sustainability and the regime type, the latter must be defined more precisely in all its possible variations. When we speak of political regime types, we can think of a continuum (cf. [43]), with the ideal (stable and contained) democracy at one extreme and a perfectly autocratic (totalitarian) regime at the other extreme, and with a broad grey area of mixed types (defective democracies, electoral autocracies) in between.
However, based on the lean definition of a democracy by Dahl (public contestation and the right to participate), one could argue that a cardinal criterion of differentiation can be found between democracies and autocracies which relates to the existence or non-existence of contested elections. Their existence, which is tied to the three conditions of "(1) ex ante uncertainty: the outcome of the election is not known before it takes place, (2) ex post irreversibility: the winner of the electoral contest actually takes office, (3) repeatability: elections that meet the first two criteria occur at regular and known intervals" ([44] p. 69), changes the 
logic-as the argument continues-of a political system in a fundamental way, since it has fundamental impact on the responsibility of the government, the citizens' possibilities to participate, and political competition in general.

The special advantage of the very lean differentiation we have chosen between democracy and autocracy, which includes neither aspects of division of powers nor of civil rights, is that it takes into account central institutional and procedural characteristics of a regime, but does not include the policy dimension, and this is especially important for the following performance evaluation [45].

For measuring the regime type, we used the current data set (DD) by Cheibub, Gandhi and Vreeland $[44,46]$, "Democracy and Dictatorship", since it is not only based on the above named criteria of differentiating between the regime types and offers a comprehensive data set in longitudinal and cross-sectional comparison, but also possesses a high degree of construct and content validity. To increase the robustness of the results of the regression we additionally used a data set presenting a combination of the popular democracy indices Freedom House and Polity [47].

What theoretical expectations can be formulated in view of the fiscal performance effect of the regime types, which-as will be shown below-are following different logics of function?

In principle, the following considerations are based on the so-called Churchill Thesis, which calls democracy the relatively best form of government (cf. [48] p. 7566). Parallel to the strengths of democracy in its fundamental fields of competence, the input legitimacy (through free and fair elections), through granting citizens participation and consideration for the preference of today's (voting) citizens (cf. [49] p. 474), can also be assumed to have advantages with regard to its fiscal sustainability performance (avoidance of financial crises, taking the interests of future generations into account, willingness to save).

Arguments supporting this can be derived first of all from considerations of institutional theory. In principle, we can assume that stable and predictable institutional arrangements would favour a sustainable policy development that depends on long-term stable framework conditions [50]. Following Padro I Miquel [51], it is precisely the autocracies that are characterized by significantly lower institutional stability in comparison with democratic societies. In contrast to those, many autocracies find it much more difficult after a change of rulers to organize a smooth transition without fundamental upheavals. However, the resulting political instabilities and ruptures could be a heavy burden to sustainable policy development and could promote indebtedness (cf. [23] p. 303). Even the uncertainty about the long-term continuity of an authoritarian regime alone canaccording to Padro I Miquel's theory-promote an inefficient type of rule that focuses on short-term goals [51], which, when in doubt, can hardly afford to be concerned with fiscal sustainability. In contrast, the institutional framework conditions in the democracies, which are more stable in the long run, increase the confidence of investors in their readiness to repay obligations (high degree of confidence) which gives them easier access to the credit market ([52] p. 36; [3] p. 2; [53]). The more favourable credit conditions, with other things being equal, not only facilitate the repayment of debts but also most likely decrease the probability of national insolvencies.

Other arguments speaking for a fiscal policy advantage of democracies can be derived from a stakeholder-centred theoretical perspective. Thus, advocates of the Rational Choice approach by Bueno de Mesquita et al. [54,55] assume that the possibility of gaining influence over political decisions is always more broadly based in democratic countries than in autocratically governed countries. Since as a rule, the electorate in democracies, in contrast to that in autocracies, consists of all eligible voters, a government-to forge a winning coalition on which its rule can be based-must to a much greater degree satisfy the interests of large parts of the population. For autocratic rulers, who only have to consider the interests of a sometimes very small winning coalition, which can consist, for example, of important military figures, high party functionaries or economic elites, it is rational to provide mainly private goods (means exclusively preferred by specific population groups) while democratic governments must offer far more public goods with a high regard for society as a whole. The prevention of payment defaults, with the associated consequences for the whole society, can be especially regarded as such public goods [56].

However, for the goal of a sustainably generationoriented fiscal policy, it is also vital to what extent the interest of future generations is being taken into consideration by the electorate, which even in democracies cannot consist of more than all the voters alive today. Based on a debate that goes back at least as far as Tocqueville [57], and is currently making a come-back namely about democracy forgetting the future $[49,58]$ the question arises whether democratic countries are finding it especially difficult to integrate the interest of future generations with their political decision-making processes just because their key concern is to cater mainly to the preferences and interests of the people living today [59]. Such a consideration of interest in democracies seems plausible especially when it can be assumed that this is connected with advantages for the majority of present generations [60]. With respect to public indebtedness, it can now be argued that in general, citizens in a democracy want to avoid this (cf. [5] p. 28), but that the urge is always there to follow a short-range strategy of maximizing expenditures [61], also due to a fiscal illusion among the electorate [62]. Under certain circumstances it is also possible in democracies, in spite of the risk of being punished by the voters, to push through spending cuts (cf. [63] p. 36) and thus to limit the shifting of burdens to future generations. The urge to maximize short-term spending decreases particularly when the consequences of excessive indebtedness, usually perceived only as diffuse future costs, become acutely manifest for 
the electorate, for example in the course of a financial crisis (cf. [5] p. 20). This may indeed present an important difference in comparison with autocratically governed states, which can continue with an indebtedness strategy even in such an event for as long as the advantage for the small winning coalition is not over-compensated by the deliberately accepted disadvantages for the country's overall economy [64].

If we then look more closely at the policy formation and decision-making processes that predominate in democracies, there could be a problem with regard to sustainable fiscal policy in spite of the potential advantages of a high free-market orientation that will be discussed below. That problem could lie in the short political time horizon that characterizes democracies. A democratic government's constant focus on meeting acutely occurring challenges under the additional pressure of constantly looming election campaigns [65] not only makes long-term planning and decision-making processes more difficult [66], but also increases the danger of excessively weighting present-day interests and pushing the problem into the future [58,67], which in turn could have negative repercussions on indebtedness performance (cf. [68] p. 59; [69]). An autocratic ruler, once firmly in the saddle, may find it easier to escape such a short-term-oriented policy development. Since he does not have to provide regular free elections, there is also no danger of an electoral business cycle. In democracies, governments are always exposed to distribute voting present before elections [70], which increases the risk of excessive leverage.

The same may apply to the influence of powerful distribution coalitions which, following Olson's argument [71], are of especially great importance in developed democracies. Their lobbying can, so the thinking goes further, make economical budgeting in the sense of fiscal sustainability more difficult (cf. [72] p. 5), unless the political decision-makers put a stop to their (usually consumptive and presence-oriented) spending wishes [73]. In particular, these distribution coalitions can also act as powerful obstacles to necessary fiscal cost-cutting programs. Corresponding studies on government fragmentation shows, that the higher the number of decision makers in democratic governments are (number of parties in a coalition, number of ministers in the cabinet, number of interest groups in the cabinet) the more difficult cost-cutting programs [74,75]. Especially in enforcing such unpleasant and sometimes harsh reforms usually directed against the interests of a majority of currently voting citizens, democratic regimes seem to have far more difficulties than autocratic regimes. On the one hand, this has to do with the fact that democratic governments cannot easily rule without facing resistance from the usually large number of institutional power limiters and veto players (established public control mechanisms). On the other hand, autocracies with their means of repression have an instrument-rarely available in democracies-to enforce a restrictive costsaving policy even against fundamental resistance among their own population.

However, these potential advantages of autocracies, which are highly controversial especially since there are fewer effective forces that can prevent reforms [76], are connected with considerable costs. Thus, the welldeveloped apparatus of repression and suppression which the autocracies must maintain because of their small input legitimization (reduced participation rights) to safeguard the stability of their regime, can cause serious financial burdens in addition to other problematic consequences [77]. The lack of public control mechanisms, which on the one hand (partially) increases the regime's ability to act, can in time complicate sustainable fiscal policy. Even if we assume - in the sense of Olson's Stationary Bandit Thesis [78] - that the expectation of a long rule in autocracies leads to a policy based on long-term goals, there will always be the latent danger that the authoritarian rule will deteriorate without effective control. The lack of institutional safety mechanisms and of political competition for leadership positions always means, at least in the long run, an inefficient policy prone to corruption and only benefitting a small group of potentates [79]. On the other hand, the publicly controlled processes of competition in democracies ensure their ability to learn and to correct errors [57], since troubles become known earlier (early warning system) and politicians are obligated through their accountability to the majority of citizens to handle public funds as prudently and transparently as possible (reduced probability of corruption). Historically, the highly competition-oriented politics in a democracy, in combination with institutional provisions and control institutions, also represents a favourable foundation for a system of market economy in general, as well as for an open and functioning capital market in particular (cf. [80] p. 206).

If after an analysis of the individual theory strands, we carefully compare all the above mentioned arguments with each other, we find that in spite of some objections (distinctive fixation with the presence, low resistance to distribution coalitions, short-term political time horizons), there are more arguments for superior sustainability performance in democratic countries (strong concern for the public good, well-defined controls on government, high institutional stability, greater ability to learn and to correct errors, strong orientation towards competition). Starting out from the theoretical considerations, two similar hypotheses can be proposed about the connection between regime type and fiscal risk management or between regime type and intergenerational justice / providing intergenerational opportunities:

Hypothesis 1: Countries with a democratic constitution find it easier than their autocratic counterparts to avoid national payment defaults.

Hypothesis 2: Altogether, democracies find it easier to lower their national debt. A democratic type of regime has a particularly dampening effect on foreign debt and a positive effect on the accumulation of foreign assets.

However, in addition to the characteristics of regime type (measured by the Democracy /Dictatorship Index and 
the data set of Hadenius and Teorell), other social, and in particular economic factors have an impact on a country's fiscal sustainability performance (cf. [81]). To accurately identify the actual impact of the regime type component, it is therefore necessary to include these factors into the investigation.

First of all, we must refer to a country's state of economic development (per capita GDP) as a central measurement. While a high level of economic development, just as a strong growth momentum, provides a country with substantial opportunities to generate income (higher tax revenues, etc.), Wagner's Law (cf. [82]) states that an economically developed society also tends to have clearly higher state spending (provision of cost-intensive government services). So we also take into account public expenditure (\% of GDP) and tax revenues (\% of GDP). While the overall effect is a matter of debate, it is probably true that altogether, a positive trade balance in a country generates additional resources for serving debts. As another relevant economic factor in connection with a country's indebtedness situation, we also considered the development of the country's inflation rate in our later investigation. Here, it can be argued that high currency devaluation in the sense of an inflationary tax can tend to lower state indebtedness (cf. [83] p. 295; [23] p. 305). The natural (energy-) resources available in a country and the interest level were also regarded as potential indicators. While on the one hand, a low interest level makes it easier to repay debts, but also is an incentive for additional new indebtedness, a country's wealth of resources can open additional sources of government income, but the intensive debate about (autocratic) rentier states shows (cf. for example, [84]) that it can also promote action by the government that is particularly inefficient and subject to corruption. With regard to factors of social structure, the population size of a country was taken into account. It can be regarded as a measure of a country's international importance. Here, it has to be examined whether the size (and thus the international relevance) of a country may possibly act as a buffer that makes a credit crunch and thus a national insolvency less likely (too big to fail). We also reviewed the effect of a society's age distribution as another factor of social culture. Theoretically, one could argue that in an ageing society (coupled with a low birth rate), the existence of powerful distribution coalitions among the older population groups [71], the interests of subsequent generations, which are difficult to organize, are systematically neglected ([85], fading intergenerational altruism), and a high senior population rate could-through increasing social expenditures-lead to pressure for higher spending (see [86] p. 175; [87]). As the last factor, we also looked at the extent in which a country is involved in military conflicts as an indicator of whether it is particularly prone to indebtedness. It is relatively easy to argue that military conflicts are generally connected with considerable government spending while they allow the revenue situation of the country to erode. Table 2 shows all explanatory factors included in the later regression analyses.

Table 2. Explanatory factors.

\begin{tabular}{ll}
\hline Explanatory factors & Description \\
\hline Regime type (Democracy/autocracy) & Democracy/Dictatorship Index. Source: [46]. \\
Regime type & Hadenius and Teorell Data Set. Source: [47]. \\
Per capita GDP & Per capita GDP: Source: [42]. \\
Growth of GDP & Annual growth of GDP, in \%. Source: [41]. \\
Public expenditure & $\%$ of GDP. Source: [42]. \\
Tax revenues & $\%$ of GDP. Source: [42]. \\
Trade balance & Trade balance. Source: [42]. \\
Inflation rate & Inflation rate. Source: [42]. \\
Energy imports & Net energy imports (\% of energy use). Source: [42]. \\
Real interest rate & Lending interest rate adjusted for inflation as measured by the GDP deflator. Source: [42]. \\
Population & Total population. Source: [42]. \\
Population ages $>65$ & Population ages 65 and above (\% of total). Source: [42]. \\
Military conflicts & Intensity of military conflicts. Source: [88]. \\
\hline
\end{tabular}

\section{Fiscal Sustainability in Comparison}

If we compare mean values of democracies and autocracies (and all their subtypes) using the four performance indicators (their general statistics are shown in Table 3) [89], the first thing that becomes apparent is that democratically governed countries are clearly better off in terms of their solvency (see Table 4). So the probability of payment defaults in democracies is clearly lower than that of their autocratic counterparts (democracies 0.15 ; autocracies 0.34 ; total average 0.22). The values expressing connections showed the same trend when we based them on simple correlation calculations between democracy and payment defaults $\left(r=-0.22^{* * *}\right)$. 
Table 3. Descriptive statistics.

\begin{tabular}{lrrrr}
\hline & Payment defaults & National debt & Foreign debt & Foreign assets \\
\hline Maximum & 1.00 & 289.80 & 812.91 & 58.30 \\
Minimum & 0.00 & 1.40 & 0.01 & 0.01 \\
Mean & 0.22 & 59.93 & 14.62 & 6.58 \\
Standard deviation & 0.43 & 38.54 & 41.82 & 3.13 \\
Number of cases & 1377 & 748 & 2394 & 2132 \\
\hline
\end{tabular}

Table 4. Comparison of Means by Type of Regime.

\begin{tabular}{lrrrr}
\hline Type of regime & Payment defaults & National debt & Foreign debt & Foreign assets \\
\hline Total (1990-2008) & 0.22 & 59.93 & 14.62 & 6.58 \\
Democracy (1990-2008) & 0.15 & 55.47 & 16.41 & 4.71 \\
Autocracy (1990-2008) & 0.34 & 69.15 & 12.49 & 9.33 \\
\hline Total (1990-1999) & 0.19 & 68.17 & 13.95 & 4.05 \\
Democracy (1990-1999) & 0.13 & 59.96 & 12.76 & 3.06 \\
Autocracy (1990-1999) & 0.26 & 77.79 & 15.23 & 5.37 \\
\hline Total (2000-2008) & 0.06 & 53.00 & 15.35 & 9.24 \\
Democracy (2000-2008) & 0.06 & 52.87 & 20.00 & 6.31 \\
Autocracy (2000-2008) & 0.07 & 53.48 & 09.09 & 14.02 \\
\hline
\end{tabular}

While the top positions were mainly held by the democracies of the OECD world, there were also some exceptions to this rule among democratically governed countries (such as Argentina), while some autocracies (Singapore, Saudi Arabia) showed good results. Particularly poor results concerning government payment defaults were shown by countries such as Russia, Iran, Myanmar and especially the autocracies on the African continent (such as Niger, Togo or Cameroon) and countries in Central and South America (for example Honduras, Nicaragua, Peru, Argentina, Brazil and Venezuela). The democracies also seem to show a slight advantage in the category of lowering national debt [90], but when we look at details, this advantage is noticeably smaller than in the category of avoiding acute payment defaults. So among the group of countries with the highest indebtedness (national debt of over $100 \%$ of GDP) are quite a few democratic industrial countries (such as Japan, Greece, Italy and Belgium). Therefore, the connection between democratic rule and national debt is also less pronounced at $r=-0.14^{* *}$.

When we look at the development of foreign debt or the accumulation of foreign assets, democratic countries are at a disadvantage. In those categories, the majority of democratically governed countries fared by no means as well as their autocratic counterparts. On the contrary, some economically emerging autocracies (China, Indonesia, Russia) did particularly well in expanding their financial reserves. Not only the average foreign debt of democracies exceeded that of the autocracies (democracies 16.41; autocracies 12.49; total average 14.62), dictatorships also seem to have been more successful in the past in accumulating foreign assets (democracies 4.71; autocracies 9.33; total average 6.58). Accordingly, there are connections between democracy and foreign debt $\left(r=0.04^{\star}\right)$ and between democracy and foreign assets $\left(r=-0.07^{\star * \star}\right)$. It would therefore certainly be out of place to speak of a general superiority of democracies across all dimensions of the study.

This impression is reinforced when we take, in addition to the full time period (1990-2008), a closer look into the sub-time periods 1990-1999 and 2000-2008 (see lower column of Table 4). While democracy advantage with regard to payment defaults and sovereign debt is much higher in the 1990s, we can see a decrease in the 2000s. Even more pronounced are the differences in foreign debt and foreign assets between the 1990s and the 2000s. While democracies had slightly less accumulated foreign debt than autocracies in the 1990s, the result revolved in the 2000s. And with regard to foreign assets autocracies obtain in the 2000s on average more than twice as much as democracies. So they build their lead significantly in relation to the 1990s.

\section{Regression Analyses}

What picture, about the connection between type of regime and fiscal sustainability performance, emerges when we take additional potential explanation factors into account in the course of multivariate regression calculations? To be able to show results as robust as possible, we calculated a total of six models for each target dimension (see in detail 
Tables 5, 6, 7 and 8). Since the stationarity of the panel was checked for each target dimension, using the LevinLin-Chu-tests and/or a consideration of the scatter plots, we could dispense the use of dynamic models. So the first two models (each with a different regime type index) provide OLS regressions with a lagged dependent variable (LDV) and panel corrected standard errors (pairwise selection; PCSE). In doing so we can fix the problem of autocorrelation of the residuals (tested with the Wooldridge test). The included lagged dependent variable explains the relatively high corrected $R^{2}$ of these models. See for the so called Beck/Katz-Standard [91]. To deal with the problem of heteroskedasticity (tested with the modified Wald test) we also calculated country-fixed-effects and time-fixed-effects models (model 3 and 4). In doing so we can see coefficients ride of specific country or year effects (for clarity reasons the results of the country and time dummy variables were not shown in the tables). Finally we added models for sub-period 1990-1999 and 20002008 (OLS with LDV and PCSE) to see whether the differences between them shown above have an influence. All explanatory variables for each model were taken into account with a time variance of one year (T-1) to test their delayed impact in time on the dependent variable.

The results listed in Tables 5-8 basically confirm the findings which already show in the comparison of means, but they also draw attention to some other interesting connections.

Thus, the models concerning payment defaults (cf. Table 5), demonstrate a significant effect in favour of democratically governed countries. This effect remains robust across all model specifications, thus confirming the previous empirical results and theoretical assumptions. However, it appears that the very strong positive effect of democracy, which is present in the 1990s, is weakening in the 2000s. While a low probability of default goes hand in hand with strong growth rate, government insolvencies coincide with a high inflation and real interest rate and seem to occur somewhat less frequently in large and aged countries. While in particular, the economic variables are thus exercising a marked influence on a country's solvency, the factor of a country being prone to war is not reaching a significant explanation level across all models.

Low national debt in a country is closely connected with a high growth rate, while the level of economic development does not appear to have such an effect (cf. Table 6 ). The variable of regime type, which is at the centre of attention here, does show that democratically governed countries tend to lower their indebtedness more, but the difference lies in most of the models below the required significant range [92].

Looking at the different time periods, the debt dampening effect, which was in force in the 1990s in favor of the democracies, turns in the 2000s into its opposite (however without reaching a high level of significance).

Definitely no advantage can be recognized for democracies when we look at foreign debt (see Table 7). Instead, the partial regression coefficient in this case shows a tendency towards higher foreign debts in democratic regimes (model 1,2 and 4), although the difference does not reach a significant level. Considering the different time periods, it is striking that in the 1990s, foreign debt in democracies was less pronounced than in autocracies (however this relationship, controlling for the other factors, does not reach high level of significance). Yet, in the 2000s, democracies accumulated significantly more foreign debt than their autocratic opponents. So situation deteriorated for the democracies over time. While the foreign debt of a country with high economic growth rates and a positive trade balance tends to be lower, aged societies seem to accumulate higher foreign debt.

Looking at the last target dimension, the size of a country, as well as its low probability of involvement in war, seems to play an important role for the accumulation of foreign assets. Positive trade balance also seems to be helpful. By contrast, democratic governance represents a signified obstacle to the accumulation of foreign assets. This effect is robust and can be observed across all model specifications. Again, the situation for democracy deteriorated considering not the 1990s but the 2000s.

In total, it can be stated that under the effect of other indicators, the regime type shows a recognizable effect in favour of democratic countries only in terms of the avoidance of payment defaults. On the other hand, they seem to be less able than their autocratic counterparts to prevent the growth of foreign debts, not to mention their greater inability to form long-term financial reserves. Particularly problematic is also the fact that democracy tends to deteriorate its impact with regard to fiscal sustainability over the last two decades. Of course this result, which is somewhat sobering for the democracies, can be somewhat brightened when we take into account that they are far more dedicated than autocracies in taking financial action in futureoriented political areas. Thus, they are able to balance the burden they place upon future generations (through excessive indebtedness) with important future investments [93]. 

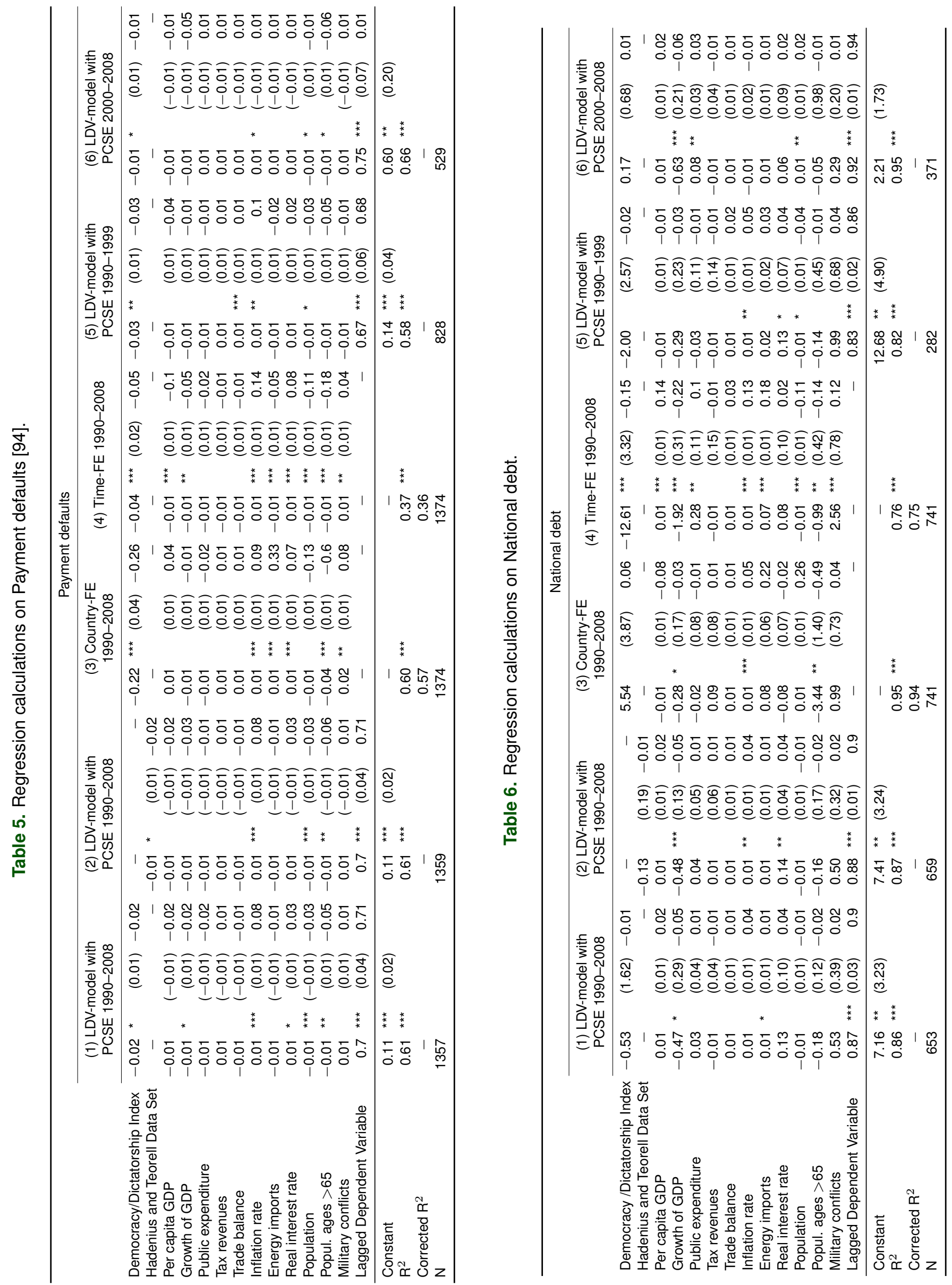

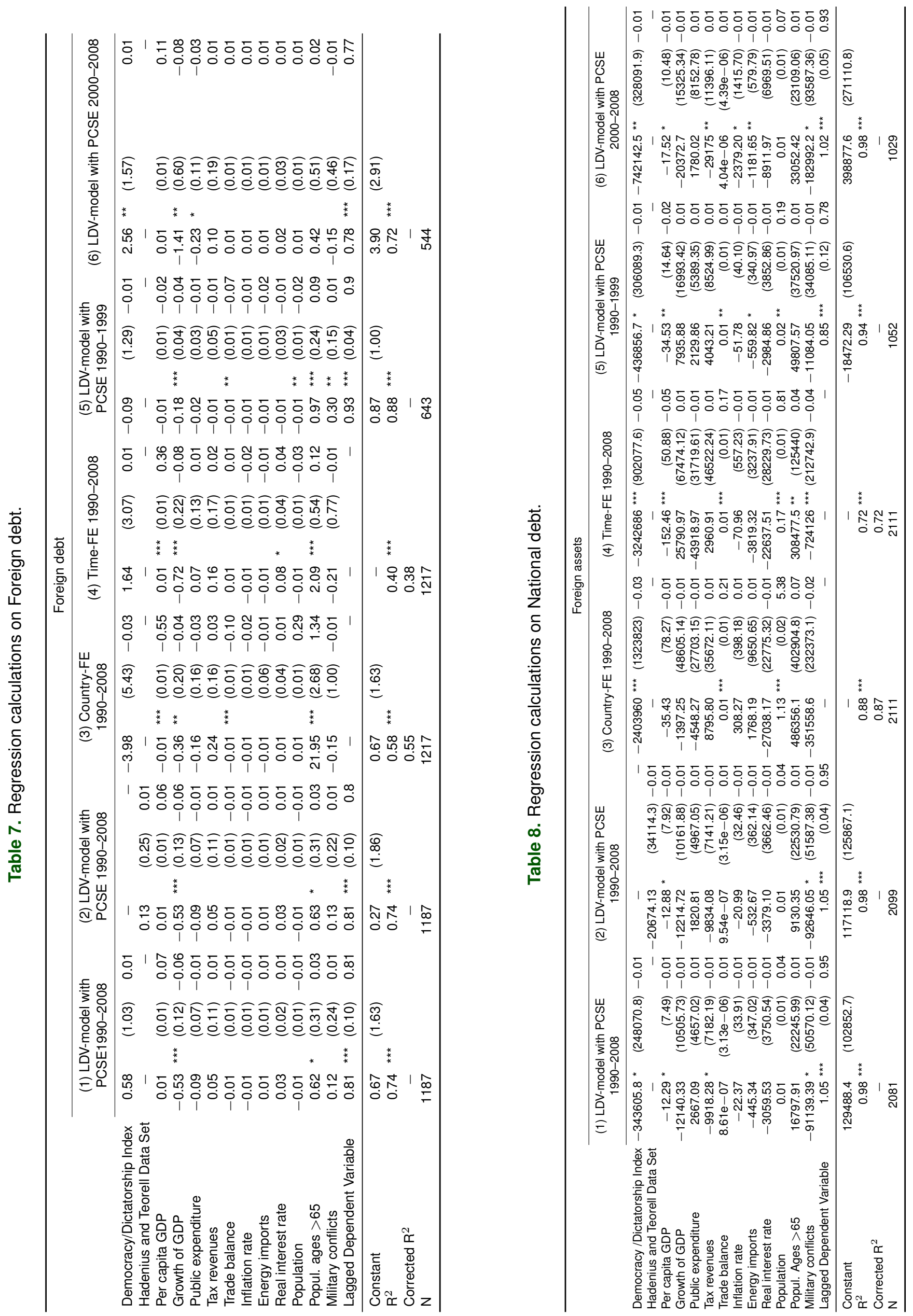


\section{Conclusion}

The objective of the study was to identify as closely as possible the financial sustainability performance of democratic and autocratic regimes by looking at five target dimensions. Financial sustainability is of fundamental importance because without it, important economic, social and environmental challenges of the future cannot be addressed. The study generates two key findings. While in the past, democracies clearly had more success than their autocratic counterparts in preserving their solvency and in avoiding national bankruptcy, a similar advantage for democracies cannot be detected when it comes to the reduction of their national debt and their foreign debt and to the accumulation of foreign assets [95]. While reliable institutional framework conditions increase confidence in the creditability of democratically governed societies (creditors worry less about non-repayment), and evidently reduce the danger of government bankruptcy, no such connection seems to exist with regard to indebtedness performance. Why democracies, in spite of existing institutional and procedural arrangements sensitive to the public good (distinctive controls of government and ability to correct mistakes, large winning coalition) are having such a hard time in avoiding to shift burdens to future generations, to undertake cost saving efforts and to use adequate financial foresight, must basically be interpreted as the other side of the coin, namely a strong orientation towards present interests. This is promoted even more by the short time horizon typical for democracies. Overall, the associated incentives for indebtedness seems to be so powerful that they not only level out any potential differences with regard to regime type, but also that they remain in place even in the face of the potentially inefficient investment policy of

\section{References}

[1] Apart from the fact that with the financial and economic crisis, even countries in the OECD world are now in danger of insolvency (cf. [96] p. 307), this theory would also be supported by historical cases of government bankruptcy (such as Argentina in 2001, India in 1972, Germany in 1932, etc.).

[2] Balkan E, Greene K. On democracy and debt. Public Choice. 1990;67(3):201-211. Available from: http://dx.doi.org/10.1007/BF00224681.

[3] Beaulieu E, Cox GW, Saiegh S. Sovereign Debt and Regime Type: Reconsidering the Democratic Advantage. International Organization. 2012 10;66:709-738. Available from: http://journals. cambridge.org/article_S0020818312000288.

[4] Oatley T. Political Institutions and Foreign Debt in the Developing World. International Studies Quarterly. 2010;54(1):175-195.

[5] Posner P, Blöndal J. Democracies and deficits: autocracies which is so prone to corruption and has little future orientation.

The results presented here are based on data that applied to the beginning of the current financial and economic crisis. For the time being, it remains to be seen to what extent they will remain robust beyond that time frame. Although the performance of democracies has tended to deteriorate in relation to autocracies over the 1990s and 2000s, past experience is giving us hope that in contrast to the autocratically governed countries, the democracies will have a greater repertoire of opportunities available to at least defend against the dangers of government bankruptcy. It remains to be seen to what extent this can be utilized in individual cases as well.

This calls attention to the need of further research which should extend from a more far-reaching analysis of connections between regime type and fiscal sustainability on a theoretical level-especially to a more precise exploration of governance structures and causal mechanisms. In addition, it seems necessary to have a detailed look at the framework conditions of financial policy and at other potential explanatory variables (cultural factors, geographical conditions, specific constellations of actors, etc.) for the policy performance analysis in this area of research that has not had much attention from the aspect of comparing regimes.

\section{Acknowledgements}

An older German version can be found under Wurster, S. Sparen Demokratien leichter?-Die Nachhaltigkeit der Finanzpolitik von Demokratien und Autokratien im Vergleich. dms-der moderne staat-Zeitschrift für Public Policy, Recht und Management. 2012; 5(2):269-290.
Prospects for fiscal responsibility in democratic nations. Governance. 2012;25(1):11-34.

[6] Wurster S. Sustainability and Regime Type: Do Democracies Perform Better in Promoting Sustainable Development than Autocracies? Zeitschrift für Staats-und Europawissenschaften (ZSE)/Journal for Comparative Government and European Policy. 2011;p. 538-559.

[7] What concerns us here is to achieve a desired general good regardless of regime type, in the sense of a systematic, target-oriented performance optimization (cf. [97] p. 550; [98] p. 304).

[8] Apart from research-pragmatic research considerations (data restrictions), we chose this period of observation because we could also include the phase since the end of the east-west conflict, which spelled significant changes in the development of the different regime types.

[9] Brundtland $\mathrm{GH}$, Hauff V, editors. Unsere gemeinsame Zukunft: Der Brundtland-Bericht. Greven: 
Eggenkamp; 1987.

[10] Grunwald A, Kopfmüller J. Nachhaltigkeit. Frankfurt am Main, Germany: Campus Verlag GmbH; 2006.

[11] von Hauff M, Kleine A. Nachhaltige Entwicklung: Grundlagen und Umsetzung. Oldenbourg Wissenschaftsverlag; 2009.

[12] Rogall H. Ökonomie der Nachhaltigkeit: Handlungsfelder für Politik und Wirtschaft. Springer-Verlag; 2013.

[13] Wurster S. Zukunftsvorsorge in Deutschland: eine vergleichende Untersuchung der Bildungs-, Forschungs-, Umwelt-und Energiepolitik. Nomos; 2010.

[14] Ward RB, Dadayan L. State and local finance: Increasing focus on fiscal sustainability. Publius: The Journal of Federalism. 2009;39(3):455-475.

[15] Rose $S$, et al. Institutions and fiscal sustainability. National Tax Journal. 2010;63(4):807-838.

[16] Brümmerhoff D. Finanzwissenschaft: Lehrund Handbücher der Wirtschafts- und Sozialwissenschaften. Oldenbourg Verlag München; 2011.

[17] A national insolvency is not desirable since it can lead to considerable system crises (cf. [23] p. 294), negative international effects (bank collapse, flight from government bond markets) as well as to the long-term loss of a country's access to credit markets (cf. [99] p. 212).

[18] Ideally this happens when a country's debt/GDP ratio is at least not prevented from increasing over a period of time through cost-saving efforts (cf. [100]). However, a government can also prevent its acute inability to meet payments by increasing taxes (see [99] p. 218 on the compulsory nature of taxation) or by increasing the money supply. Both measures encompass economical perils. For example, out-ofcontrol inflation can have the result that the country's currency loses its function (cf. [21] p. 96).

[19] Sachverständigenrat zur Begutachtung der gesamtwirtschaftlichen Entwicklung/ Conseil d'Analyse économique. Wirtschaftsleistung, Lebensqualität und Nachhaltigkeit: Ein umfassendes Indikatorensystem. Expertise im Auftrag des DeutschFranzösischen Ministerrates; 2010. Available from: http://www.sachverstaendigenrat-wirtschaft.de/ fileadmin/dateiablage/Expertisen/2010/ex10_de.pdf.

[20] Sachverständigenrat zur Begutachtung der gesamtwirtschaftlichen Entwicklung. Staatsverschuldung wirksam begrenzen. Expertise im Auftrag des Bundesministeriums für Wirtschaft und Technologie. Wiesbaden: Sachverständigenrat zur Begutachtung der gesamtwirtschaftlichen Entwicklung, Statistisches Bundesamt; 2007.

[21] Hansmann M. Vor dem dritten Staatsbankrott?: Der deutsche Schuldenstaat in historischer und internationaler Perspektive. Oldenbourg Verlag; 2012.

[22] Primarily, the difference between the long-term credit financing of public expenditures and financing through taxation is "intergenerational redistribution at the expense of future generations" ([20] p. 31).

[23] Wagschal U. Wer ist schuld an den Schulden? Zur Politischen Ökonomie der Staatsverschuldung. In: Obinger H, Wagschal U, Kittel B, editors. Politische Ökonomie: Demokratie und wirtschaftliche Leistungsfähigkeit. Springer-Verlag; 2003. p. 289-320.

[24] Konrad KA, Zschäpitz H. Schulden ohne Sühne? Was Europas Krise uns Bürger kostet. Deutscher Taschenbuch Verlag; 2012.

[25] In those cases, debt financing seems justifiable. "In those cases, financing through taxation would be connected either with an unjustifiably high burden for present generations or would have a strongly procyclical effect" ([20] p. 6, translation by the author).

[26] According to the Pay-as-you-use principle, the cost of public investments can be stretched out over time through indebtedness (cf. [23] p. 295, [21] p. 26) "to also include the future beneficiaries of today's (investment) expenditures in the burden of financing" ([20] p. 1). However, the crucial factor is that it must be "investments increasing public assets" ([20] p. 3) which also benefit future generations according to the burden-sharing principle (cf. [29] p. 7).

[27] Becker A. Generationengerechte Finanzpolitik. In: Tremmel J, editor. Handbuch Generationengerechtigkeit. ökonom; 2003.

[28] However, should the GDP growth rate exceed the rate of indebtedness, it is also possible for a country to grow out of debt in the sense of Ponzi Schemes and the Harrod Domar Model, since tax revenues increase faster than the interest payable. Furthermore, in that case, the indebtedness should be classified as Pareto efficiency, since the introducing generation profits from it "without ever burdening the subsequent generations" [20] p. 41).

[29] Boettcher F, Tremmel J. Generationengerechtigkeit in der Finanzverfassung. Stiftung für die Rechte zukünftiger Generationen; 2005.

[30] Süssmuth B, von Weizsäcker RK. Institutional determinants of public debt: a political economy perspective. In: Tremmel J, editor. Handbook of Intergenerational Justice. Edward Elgar, Cheltenham; 2006. p. 170-184.

[31] Weizsäcker RKv. Repräsentative Demokratie und öffentliche Verschuldung: Ein strategisches Verhängnis. Technische Universität München; 2009.

[32] Baker B, Besendorfer D, Kotlikoff LJ. Intertemporal State Budgeting. 2002. Available from: http://www. kotlikoff.net/sites/default/files/ISB6-4-02.pdf.

[33] However, it can be assumed that the implicit indebtedness ([32] p. 2) for practically all countries will be systematically above the explicitly identified indebtedness (cf. [101]).

[34] They are described in detail in Table 1.

[35] Roller E. Comparing the performance of autocracies: Issues in measuring types of autocratic 
regimes and performance. Contemporary Politics. 2013;19(1):35-54.

[36] Systematic empirical studies reveal that the number of missing values is considerably higher for undemocratic countries than democratic ones ([35], [102]). In addition, a selection bias can occur when autocracies provide information especially "if they are compelled to by an outside agency (i.e. the World Bank, the International Monetary Fund or the United Nations Development Program), and outside agencies only make these demands when countries approach them for assistance" ([103] p. 864).

[37] Enderlein H, Trebesch C, von Daniels L. Sovereign debt disputes: A database on government coerciveness during debt crises. Journal of International Money and Finance. 2012;31(2):250-266.

[38] Beaulieu E, Cox GW, Saiegh SM. Replication data for: Sovereign debt and regime type: Reconsidering the democratic advantage. 2012. Available from: http://hdl.handle.net/1902.1/17458UNF: 5:aq2nMTz6ou8Lh9ZDixvSTA.

[39] In this connection, it would have been desirable to use not only the explicit, but also the implicit national debt [104], which would include for example a country's long-term pension obligations. This was not possible due to data restrictions.

[40] As a qualifier in terms of the data situation, it must be said that only emerging countries and developing countries could be included in this indicator.

[41] In the following, one star stands for a significance level of $90 \%$, two stars for $95 \%$ and three stars for $99 \%$.

[42] The World Bank. The World at a Glance. 2012. Available from: http://data.worldbank.org.

[43] Merkel W. Systemtransformation. Eine Einführung in die Theorie und Empirie der Transformationsforschung; 2010.

[44] Cheibub JA, Gandhi J, Vreeland JR. Democracy and dictatorship revisited. Public Choice. 2010;143(12):67-101.

[45] This distinguishes it from a very broad definition of democracy which we find for example in the Gettysburg Address (Government of the people, by the people, and for the people) or in the concept of embedded democracy that regards political and civil freedoms, equality and control as the constitutional characteristics of a democracy ([43], [105] p. 95).

[46] Cheibub JA, Gandhi J, Vreeland JR. Democracy and dictatorship revisited Codebook. 2009. Available from: https://netfiles.uiuc.edu/cheibub/www/ DD_page.html.

[47] Hadenius A, Teorell J. Authoritarian Regimes Data Set, version 2.1 Codebook. Journal of Democracy. 2010;18(1):143-156.

[48] Churchill W, James RR. Winston S. Churchill: His Complete Speeches, 1897-1963: His Complete Speeches, 1897-1963. Chelsea House Publica- tions; 1974

[49] Schmidt MG. Demokratietheorien: Eine Einführung. 5th ed. VS Verlag für Sozialwissenschaften; 2010.

[50] Gandhi J. Political institutions under dictatorship. Cambridge University Press; 2008.

[51] Padró i Miquel G. The control of politicians in divided societies: The politics of fear. The Review of Economic Studies. 2007;74(4):1259-1274.

[52] Schultz KA, Weingast BR. The democratic advantage: institutional foundations of financial power in international competition. International Organization. 2003;57(01):3-42.

[53] However, simple access to the credit market can turn out to be a double-edged sword, since it can be an incentive to indebtedness. Thus, the confidence of a democracy's citizens would actually promote (especially inland) indebtedness (cf. [106] p. 65), while autocracies, apart from the high burden of taxation placed on those under their rule, are increasingly prepared to accept the danger of high foreign debt, especially when their power base is not in immediate danger, not even in case of insolvency and its overall negative economic impact.

[54] Bueno de Mesquita B, Morrow JD, Siverson RM, Smith A. Political institutions, policy choice and the survival of leaders. British Journal of Political Science. 2002;32(04):559-590.

[55] Bueno de Mesquita B, Smith A. The logic of political survival. MIT Press; 2005.

[56] The prevention of government insolvency requires not only the ability but also the willingness to take appropriate counter measures (cf. [106] p. 54), which means that the political leadership has to play a central role in setting priorities.;

[57] De Tocqueville A. De la démocratie en Amérique. Librairie de Charles Gosselin; 1842.

[58] Kielmansegg PG. Können Demokratien zukunftsverantwortlich handeln? Merkur Deutsche Zeitschrift für europäisches Denken. 2003;(651):583-594.

[59] Höffe O. Ist die Demokratie zukunftsfähig?: Über moderne Politik. C.H. Beck; 2011.

[60] The less this is the case (on the problem of discounting the future, see [107]), the more pronounced would be a possible positive democracy effect.

[61] Indebtedness is a politically very attractive way to achieve "perceptible expenditures with imperceptible revenues" ([108] p. 58-to spend without to tax).

[62] "They ignore the government's intertemporal budget restriction and do not realize that additional expenditures today are connected with a greater tax burden tomorrow, or they underestimate the 'tax cost' of providing more public goods. Opportunistic politicians are exploiting this situation and increase government spending to gain votes" ([108] p. 51, translation by the author).

[63] Zohlnhöfer R. Globalisierung der Wirtschaft und finanzpolitische Anpassungsreaktionen in Westeu- 
ropa. Nomos; 2009.

[64] In autocracies, it is not only future generations that are negatively affected by excessive indebtedness (problem of future discounting). The effect in those countries can also be negative on a majority of the present population, and it is still not remedied (cf. [4] p. 180).

[65] Linz JJ. Democracy's time constraints. International Political Science Review. 1998;19(1):19-37.

[66] "Foresight is a politically unnatural act by elected officials who primarily focus on their next election far more than they do on the fiscal prospects facing the nation 20 years from now" ([5] p. 18, translation by the author).

[67] While democracies, as argued above, can provide an institutional framework in the long run that is more stable than that of autocracies, the political processes taking place within that framework are oriented towards a very short time horizon.

[68] Weizsācker RKV. Staatsverschuldung und Demokratie. Kyklos. 1992;45(1):51-67.

[69] By acquiring excessive debts in the presence, a government also has a possibility to greatly restrict future governments' freedom of action (with possibly contrary political priorities-cf. [24] p. 143).

[70] Alesina A, Cohen GD, Roubini N. Electoral business cycle in industrial democracies. European Journal of Political Economy. 1993;9(1):1-23.

[71] Olson M. The rise and decline of nations: Economic growth, stagflation, and social rigidities. Yale University Press; 2008.

[72] Gerard MR, Ruiz FMM. Corporate taxation and the impact of governance, Political and economic factors. CESifo Working Paper Series No. 2904. 2009. Available from: http://papers.ssrn.com/sol3/papers. cfm?abstract_id $=1536431$.

[73] Within democracies it can be shown that their lobby work (for cost-intensive measures such as in the social system) finds a sympathetic ear mainly in the legislature, while the executive finds it easier to withdraw (cf. [15] p. 816).

[74] Bohn H, Inman RP. Balanced-budget rules and public deficits: evidence from the US states. In: Carnegie-Rochester conference series on public policy. vol. 45. Elsevier; 1996. p. 13-76.

[75] Perotti R, Kontopoulos Y. Fragmented fiscal policy. Journal of Public Economics. 2002;86(2):191-222.

[76] Thus, it can be argued that in autocracies, too, there are numerous veto players, but due to particularly non-transparent decision-making processes, they are not always easy to identify.

[77] According to the Dictator's Dilemma discovered by Wintrobe $([109,110])$ this effect is even further intensified. In time, the use of repressive means leads to a distorted perception of reality by the political leadership which is no longer supplied with reliable information by those subjected to the rule (inadequate political feedback loop). This leads not only to a continuously greater expansion of the repression apparatus, which can sometimes assume paranoid proportions, but it can also lead to a regime's very costly miscalculations in terms of economic and fiscal policy.

[78] Olson M. Dictatorship, Democracy, and Development. American Political Science Review. 1993;87(03):567-576.

[79] "The assumption is that if a dictator can't be easily removed from office, he will perform very poorly" ([111] p. 7; [112] p. 6).

[80] Heinze RG. Rückkehr des Staates? Politische Handlungsmöglichkeiten in unsicheren Zeiten. Springer; 2009.

[81] Boix C, Stokes SC. The Oxford handbook of comparative politics. Oxford University Press; 2007.

[82] Wagner A. Grundlegung der politischen Ökonomie. vol. 1 Grundlagen der Volkswirtschaft. C.F. Winter; 1893.

[83] Chalk NA. The sustainability of bond-financed deficits: An overlapping generations approach. Journal of Monetary Economics. 2000;45(2):293-328.

[84] Haber S, Menaldo V. Do natural resources fuel authoritarianism? A reappraisal of the resource curse. American political science Review. 2011;105(01):126.

[85] Weede E. Wirtschaft, Staat und Gesellschaft: zur Soziologie der kapitalistischen Marktwirtschaft und der Demokratie. Mohr Siebeck; 1990.

[86] Wagschal U, Wenzelburger G. Haushaltskonsolidierung. Springer; 2008.

[87] Lodge M, Hood C. Into an age of multiple austerities? Public management and public service bargains across OECD countries. Governance. 2012;25(1):79-101.

[88] Schwank N. CONIS-Affected countries 19452008. 2012. Available from: www.conis.org.

[89] Apart from the maximum and minimum possible characteristics of each indicator, we also show the mean, the standard deviation and the number of cases.

[90] While the democracies showed an average national debt of $55.47 \%$ of their GDP, the corresponding figure for autocracies was $69.15 \%$ of GDP (total average: $59.93 \%$ of GDP).

[91] Beck N, Katz JN. What to Do (and Not to Do) with Time-Series Cross-Section Data in Comparative Politics. American Political Science Review. 1995;634:634-35.

[92] Democratic investment opportunities seem to have no significant positive effect on reducing the national debt. See also $[6,113]$, with regard to similar results.

[93] It can be shown, for example, that democracies invest significantly more in their health system ( $r$ $\left.=0.40^{* * *}\right)$ and in their R\&D and development infrastructure $\left(r=0.34^{* \star *}\right)$, while autocracies (and in 
particular the military autocracies) are spending far more for military purposes $\left(r=-0.22^{* * *}\right)$. The data for all these figures come from The World Bank, 2012. These connections between regime type and individual areas of expenditure remain robust even when examined in the course of multivariate regression calculations taking into account all the control figures listed in Table 2.

[94] One star stands for a significance level of $90 \%$, two stars for $95 \%$ and three stars for $99 \%$. In the left upper field of each variable is the partial regression coefficient, under it in brackets is the standard error for the estimation, and to the right is the standardized partial regression coefficient.

[95] Thus, Hypotheses 1 derived from theoretical considerations is verified, while this does not apply to $\mathrm{Hy}$ pothesis 2 .

[96] Wagschal U, Jäkel T. Öffentliche Finanzen im Stresstest-Policy-Reaktionen auf die Finanzund Wirtschaftskrise. dms-der moderne staatZeitschrift für Public Policy, Recht und Management. 2010;3(2).

[97] Roller E. Leistungsprofile von Demokratien. Eine theoretische und empirische Analyse für westliche Demokratien, 1974-1995. Fuchs D, Roller E, Wessels B, editors. Springer; 2002.

[98] Roller E. Performanz. In: Göhler G, Iser M, Kerner I, editors. Politische Theorie: 22 umkämpfte Begriffe zur Einführung. VS Verlag für Sozialwissenschaften; 2004. p. 297-314.

[99] Blankart CB. Wie viel Schulden dürfen wir den nachfolgenden Generationen überlassen? In: Goldschmidt N, editor. Generationengerechtigkeit. Mohr Siebeck; 2009. p. 205-224.

[100] Blanchard O, Chouraqui J-C, Hagermann RP, Sartor N. The Sustainability of Fiscal Policy: New Answers to an Old Question. OECD Economic Studies 15; 1990. Available from: http://www.oecd.org/ dataoecd/50/21/34288870.pdf.

[101] Moog S, Raffelhüschen B. Ehrbare Staaten? Tatsächliche Staatsverschuldung im Vergleich. Stiftung Marktwirtschaft;. Agumente zur Mark- twirtschaft und Politik No. 115.

[102] Hollyer JR, Rosendorff BP, Vreeland JR. Democracy and transparency. The Journal of Politics. 2011;73(04):1191-1205.

[103] Ross M. Is democracy good for the poor? American Journal of Political Science. 2006;50(4):860-874.

[104] Kotlikoff LJ, Burns S. The clash of generations: saving ourselves, our kids, and our economy. MIT Press; 2012.

[105] Croissant A. Analyse defekter Demokratien. In: Schrenk KH, Soldner M, editors. Analyse demokratischer Regierungssysteme. Springer; 2010. p. 94-114.

[106] Reinhart CM, Rogoff K. This time is different: eight centuries of financial folly. Princeton University Press; 2009.

[107] Birnbacher D. Läßt sich die Diskontierung der Zukunft rechtfertigen. In: D B, Brudermüller G, editors. Zukunftsverantwortung und Generationensolidarität. Königshausen \& Neumann; 2001. p. 117136.

[108] Wenzelburger G. Haushaltskonsolidierungen und Reformprozesse: Determinanten, Konsolidierungsprofile und Reformstrategien in der Analyse. LIT Verlag; 2010.

[109] Wintrobe R, et al. The political economy of dictatorship. Cambridge University Press; 1998.

[110] Wintrobe R. Dictatorship: analytical approaches. In: Boix C, Stokes S, editors. The Oxford Handbook of Comparative Politics. Oxford University Press; 2009. p. 363-394.

[111] Besley TJ, Kudamatsu M. Making Autocracy Work. Centre for Economic Policy Research; 2007. DP6371. Available from: http://www.cepr.org/active/ publications/discussion_papers/dp.php?dpno=6371.

[112] Clark WR, Poast P, Flores T, Kaufman RR. Why some Autocracies perform so well; 2011. Unpublished manuscript.

[113] Lafferty WM, editor. Governance for sustainable development: the challenge of adapting form to function. Edward Elgar Publishing; 2006. 